\title{
Yield composition of two-rowed and multi-rowed barleys in drilled and single-plant populations in southern and northern Finnish experiments
}

\author{
KIRSTI ÄyräVÄINEN \\ Department of Plant Husbandry, University of Helsinki, $00710 \mathrm{Helsinki}$
}

\begin{abstract}
Northern location was found to accelerate the development of multirowed barley varieties more than that of two-rowed varieties. In drilled trials tworowed varieties even required longer growing periods in the north than in the south.

Single-plant populations developed more slowly than drilled populations and produced larger biological and grain yields per plant. They also produced higher numbers of culms and ears and higher proportions of leaves in the biological yield than the drillsown trials. On the other hand, adventitious shoots were more abundant and the ratio of grain yield to biological yield was lower in the single-plant trials than in the drilled trials.

In general, multi-rowed varieties were significantly earlier than two-rowed varieties. In single-plant trials the two-rowed barleys, due to their good tillering capacity, gave a larger biological yield than the multi-rowed barleys. Grain yield in single-plant trials was in the south higher from the two-rowed varieties but in the north from the multirowed varieties. There were no differences due to barley type or locality in the proportions of different plant organs in the biological yield.

Correlation coefficients between grain yield and some factors affecting it is also treated.
\end{abstract}

In breeding of cereal varieties with highest possible yielding potential, various factors of the yield have been under separate consideration ever since the 1920's (Engledow and Wadham 1923). Besides the actual yield components, viz. number of headed culms, number of grains per ear, and grain weight, attention has been directed in the past few decades to various other physiological and morphological factors. The core of the many works published on this subject has been reviewed by THORNE (1966) and LANGer (1967). According to Thorne the size of grain yield depends mainly on the flag leaf and the assimilating plant parts situated above it. Langer similarly names assimilation as the prime factor but also emphasizes the importance of dry-matter distribution as well as that of the relationship between environmental and physiological factors in determining the yield.

The aim of the present study was to investigate the formation and composition of yield in two- and multi-rowed barley varieties as well as the distribution of biological yield within the barley plants when grown in drill-sown and single-plant populations in southern and northern Finnish experiments. 


\section{Material and methods}

The following seven barley varieties were chosen for the experiments: Arvo, Birgitta, Arla, and $\mathrm{Hja} 34003$ (all two-rowed), and Tammi, Pirkka, and Pomo (multi-rowed). The two-rowed Arla and the multi-rowed Pomo are varieties derived from crossings between the two types.

The experiments were conducted by the Department of Plant Husbandry at two localities, University Farm Viikki, Helsinki $\left(60^{\circ} 10^{\prime} \mathrm{N}\right)$ and the Viskaali field station of Hankkija at Muhos near Oulu $\left(64^{\circ} 55^{\prime} \mathrm{N}\right)$ in the years 1971-72. The experiments consisted of normally drill-sown plot trials and single-plant populations. Plot size in the drilled trials was $10 \mathrm{~m}^{2}$, seed rate $175 \mathrm{~kg} /$ ha of $100 \%$ germinating seed with a 1000 -grain weight of $40 \mathrm{~g}$. The single plants were spaced at $40 \times 40 \mathrm{~cm}$. There were five replications except for the Muhos single-plant trials where the number of replications was four. Normal management practices were followed during the growing season.

Plant samples were harvested at five different developmental stages from $25 \mathrm{~cm}$ lengths of drilled row; in the spaced populations the samples consisted of eight plants. The stages of harvest were

1. Lateral shoots formed

2. Culm growth initiated, first node visible

3. Awns emerged

4. Anthesis passed, grains filling

5. Full maturity.

The numbers of plants and culms in the samples were counted and dry weights determined separately for leaves, culms and ears. Ear lengths were measured, grains threshed out and weighed, 1000 -grain weights and grain nitrogen contents determined. At the end of the season the entire drilled plots were harvested and hectare yields and hectolitre weights of the grain determined.

The single-plant trials at Muhos were harvested at stages $\mathbf{3 - 5}$ only.

\section{Weather and daylength conditions}

Temperature, rainfall and daylength data for the two growing seasons 1971 and 1972 are presented in Fig. 1. The records are from the nearest meteorological stations Helsinki and Oulu.

Both seasons were warmer than normal. The following sums of day degrees for 90 days subsequent to sowing show only a slight difference in temperature between the experimental localities:

\begin{tabular}{|c|c|}
\hline & Tem $_{1}$ \\
\hline & 1971 \\
\hline Helsinki ........................... & 1336 \\
\hline Oulu & 1285 \\
\hline
\end{tabular}

In 1971 the early summer was very dry in both districts; in 1972 conditions were more favourable. Sprinkler irrigation was applied at Viikki when necessary but no irrigation was available at Muhos. 

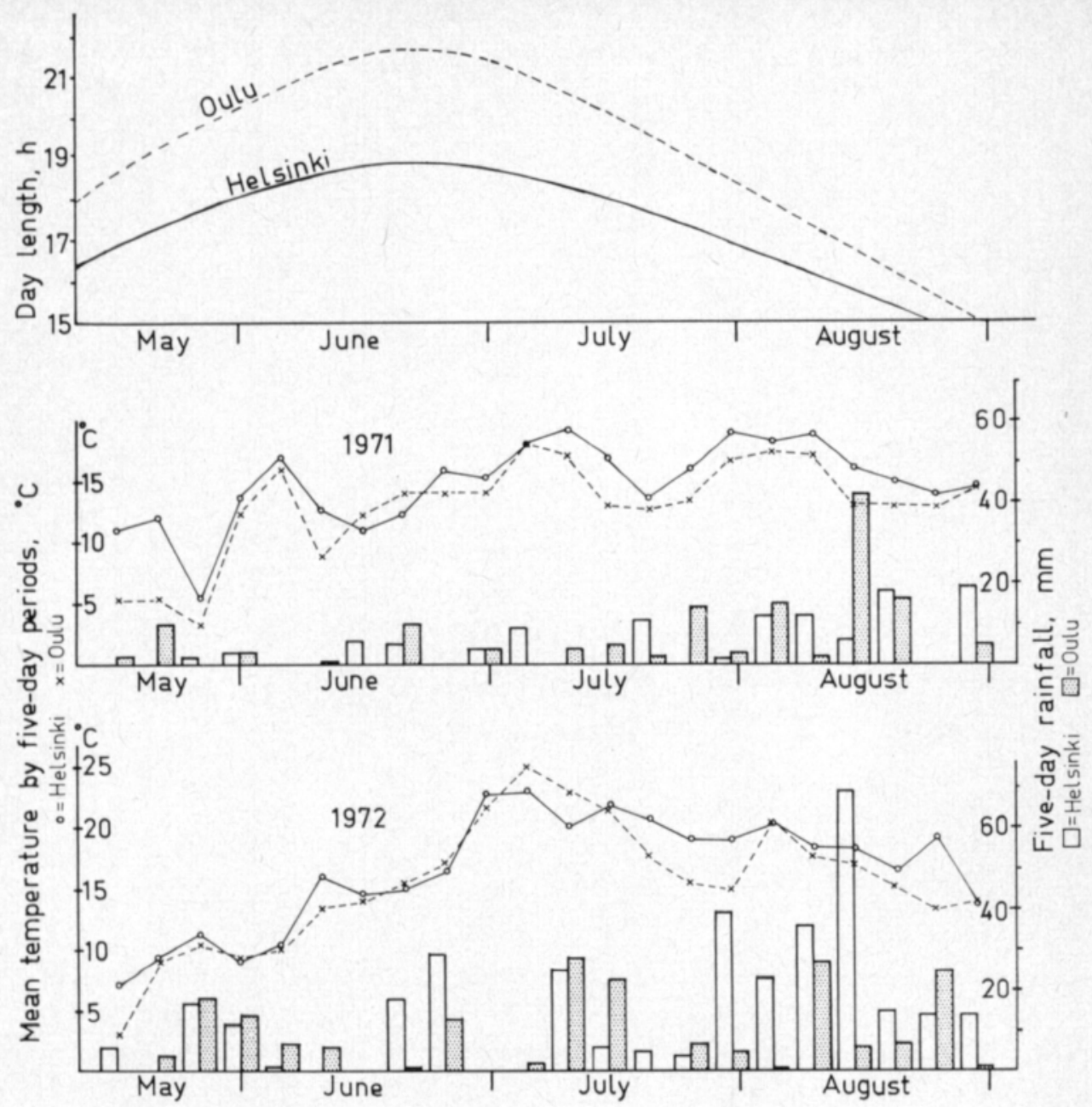

Fig. 1. Daylength, temperature and rainfall in the growing seasons of $1971-72$. Data from meteorological stations nearest to the experimental localities, Helsinki and Oulu.

\section{Results}

\section{Rate of development}

Development was much slower in the spaced than in the drill-sown populations. The difference ranged from one day at the first (stage 1) harvest to as much as four weeks at the last (stage 5) harvest. Early growth was faster at Muhos than at Viikki. Maturing of the spaced plants was likewise faster at Muhos than at Viikki (Table 1). In the drilled experiments at Muhos, however,

Table 1. Length of growing period in days from sowing to maturing

\begin{tabular}{|c|c|c|c|c|}
\hline & \multicolumn{2}{|c|}{ Drill-sown trials } & Single-plant trials & $\begin{array}{l}\text { trials } \\
\text { Muhos }\end{array}$ \\
\hline Two-rowed varieties ................. & 91,2 & 94,8 & 114,2 & 104,6 \\
\hline Multi-rowed varieties ................ & 87,9 & 84,5 & 114,7 & 99,2 \\
\hline
\end{tabular}




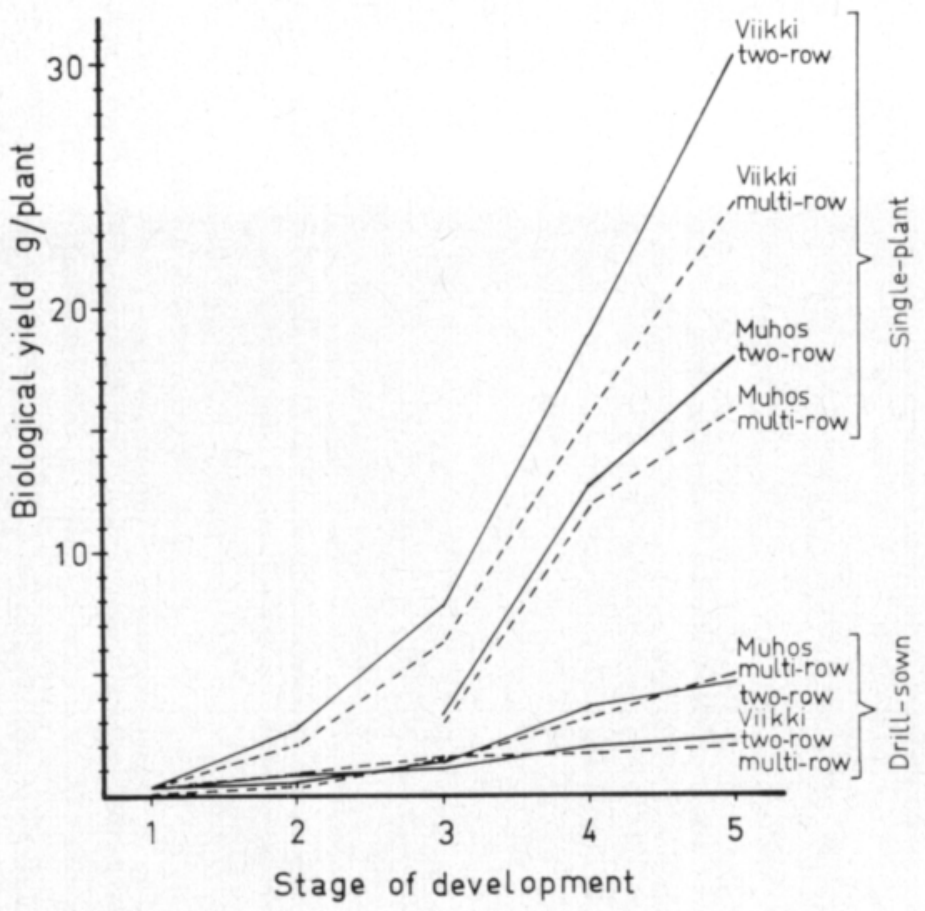

Fig. 2. Total biological yield per plant of the two- and multi-rowed barley varieties in drillsown and single-plant trials at Viikki and Muhos.

where development prior to and during anthesis was faster than at Viikki, final maturing took place so slowly that the total growing period for the two-rowed varieties there turned out even longer than for those at Viikki. $\mathrm{Hja} 34003$ and Arvo required the longest growing periods, Tammi, Pirkka, and Arla the shortest.

\section{Total biological yield}

Biological yield per plant (Fig. 2) was many times greater in the spaced than in the drilled trials. The single-plant trials gave larger yields at Viikki than at Muhos but the drilled trials yielded better at Muhos. In the singleplant trials the biological yield of the two-rowed varieties was at both localities significantly larger than that of the multi-rowed varieties; in the drilled trials there was little difference. Towards the end of the growing season, however, two-rowed varieties in the drilled trials at Viikki gave a significantly higher biological yield than the multi-rowed varieties. At Muhos the two-rowed varieties which still in the fourth harvest gave a larger biological yield, remained slightly below the multi-rowed varieties at the last harvest.

In the drill-sown trials there were no significant differences in biological yield between the varieties at any stage of development. In the spaced trials, too, varietal differences in biological yield were small at Muhos but rather large at Viikki. Arvo, $\mathrm{Hja} 34003$ and Pomo were the best yielding varieties, Tammi and Pirkka the poorest. 
Fig. 3. Leaves per cent of total biological yield of the two- and multi-rowed barley varieties in drillsown and single-plant trials at Viikki.
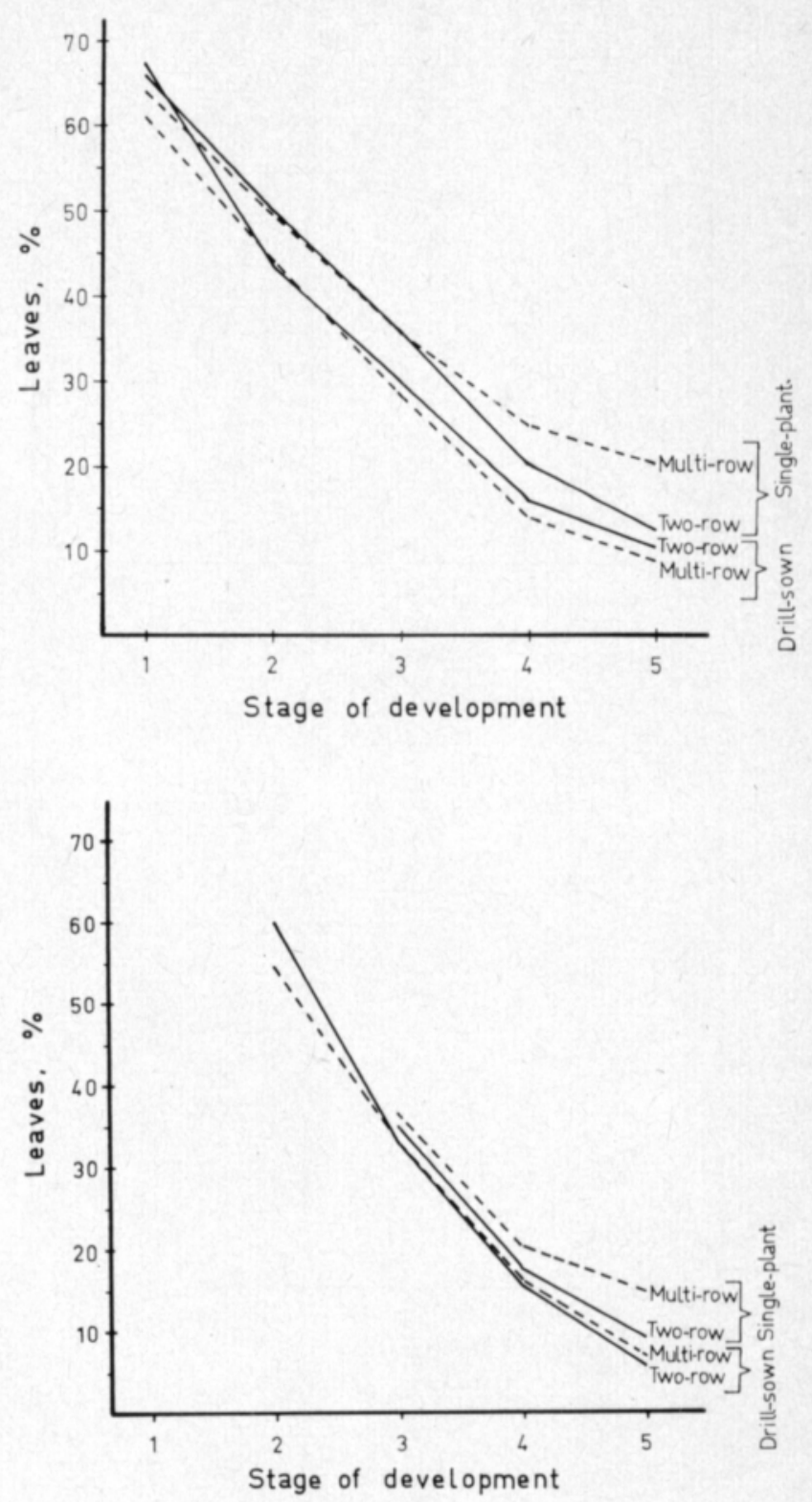

Fig. 4. Leaves per cent of total biological yield of the two- and multi-rowed barley varieties in drill-sown and single-plant trials at Muhos.

\section{Percentage of leaves in biological yield}

Leaf percentages were higher in single-plant trials than in drilled trials (Figs. 3 and 4). In the single-plant trials at both localities the multi-rowed varieties had very significantly larger proportions of leaves in the late stages of development than had the two-rowed varieties. In the drill-sown trials at Viikki the two-rowed varieties had significantly higher leaf percentages in the late stages of development than had the multi-rowed varieties, whereas in the Muhos drilled trials the result was the reverse. The least leafy variety, Tammi barley, had about $10 \%$ less leaves than the average for all varieties throughout the developmental period. The leafiest, Pomo, surpassed the 

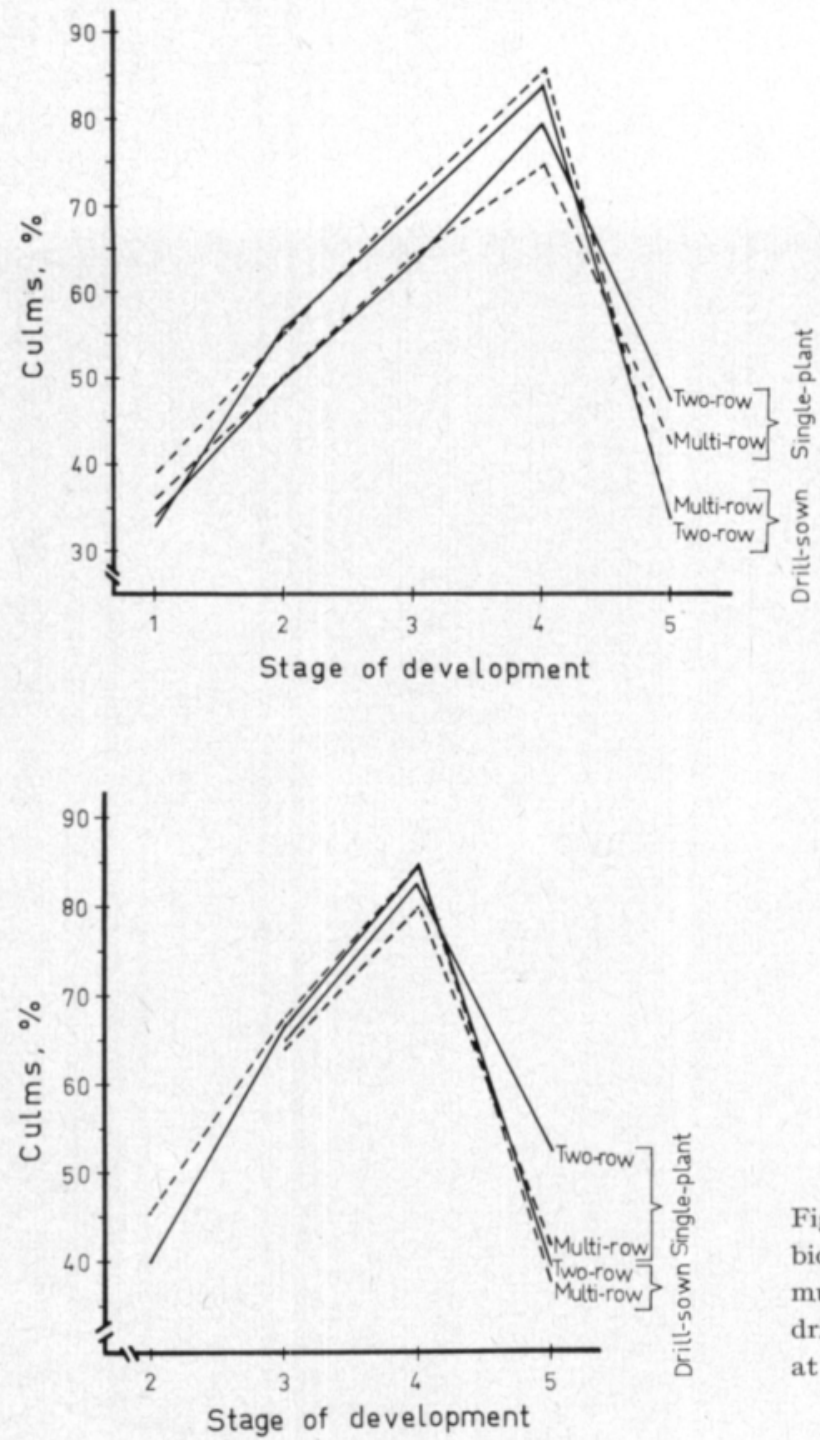

Fig. 5. Culms per cent of total biological yield of the two- and multi-rowed barley varieties in drill-sown and single-plant trials at Viikki.
Fig. 6. Culms per cent of total biological yield of the two- and multi-rowed barley varieties in drill-sown and single-plant trials at Muhos.

others slightly during the vegetative phase already and had an almost double percentage of leaves in comparison with the other varieties after the emergence of ears.

\section{Percentage of culms in biological yield}

In the course of maturing the proportion of culms in the spaced trials rose higher than in the drilled trials (Figs. 5 and 6). Prior to maturing there were higher culm percentages in the drilled trials especially at Viikki. There was no significant difference between the two localities in this respect. From the emergence of awns onwards, the two-rowed varieties in single-plant populations had significantly higher percentages of culms than the multi-rowed varieties. In drill-sown trials the types did not differ. Two varieties deviated clearly 
Fig. 7. Number of culms per plant of the two- and multi-rowed barley varieties in drill-sown and singleplant trials at Viikki.

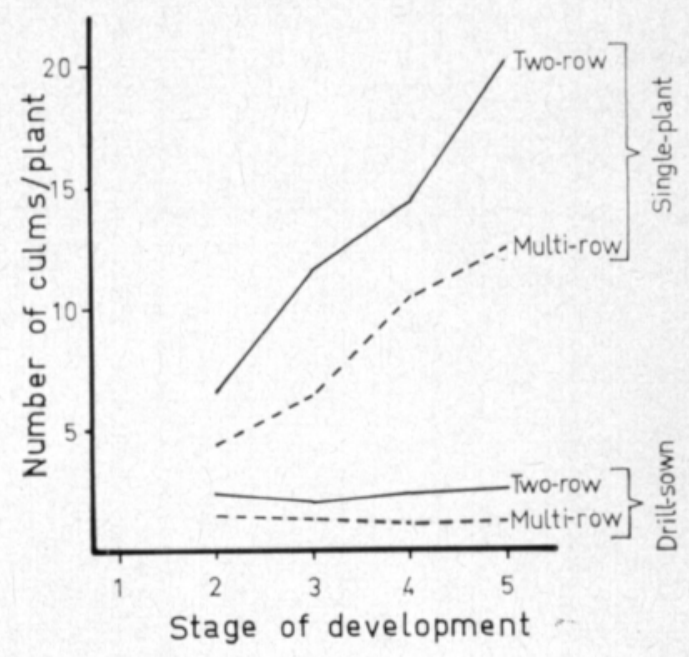

from the average for all varieties: Tammi with its significantly higher culm percentages up to the beginning of maturing, and Pomo with its below-average figures throughout the experimental period.

\section{Percentage of ears in biological yield}

Ears comprised 53-60\% of the mature biological yield in the drill-sown trials and $32-47 \%$ in the spaced trials. There were no significant differences between the localities. Significant differences between varieties occurred in the Muhos single-plant trials only where the highest ear percentage $(47 \%)$ was obtained for Tammi and the lowest (32\%) for $\mathrm{Hja} 34003$.

\section{Number of culms}

In the drill-sown populations the number of culms per plant did not change from the second harvest to the fifth (Fig. 7). In the single-plant populations, however, the number of culms approximately trebled in the same period. At Muhos there were significantly fewer culms in the spaced trials than at Viikki, and their number did not significantly exceed the number of culms in the drill-sown trials, as was the case at Viikki (Fig. 8). In drilled trials all the multi-rowed varieties (Tammi, Pirkka, Pomo) had significantly lower numbers of culms than the two-rowed varieties (Fig. 8). In single-plant trials, on the other hand, the multi-rowed Pomo equalled the two-rowed varieties in number of culms.

\section{Adventitious shoots}

In the drill-sown populations at Viikki there was very little adventitious shooting as compared with the Muhos experiments (Fig. 9). This was probably due to the fact that artificial irrigation was applied at Viikki early in the season whereas none was applied at Muhos. At both localities adventitious shooting occurred to a much greater extent in the spaced than in the drilled trials. Large varietal differences were observed. The two-rowed varieties produced more 


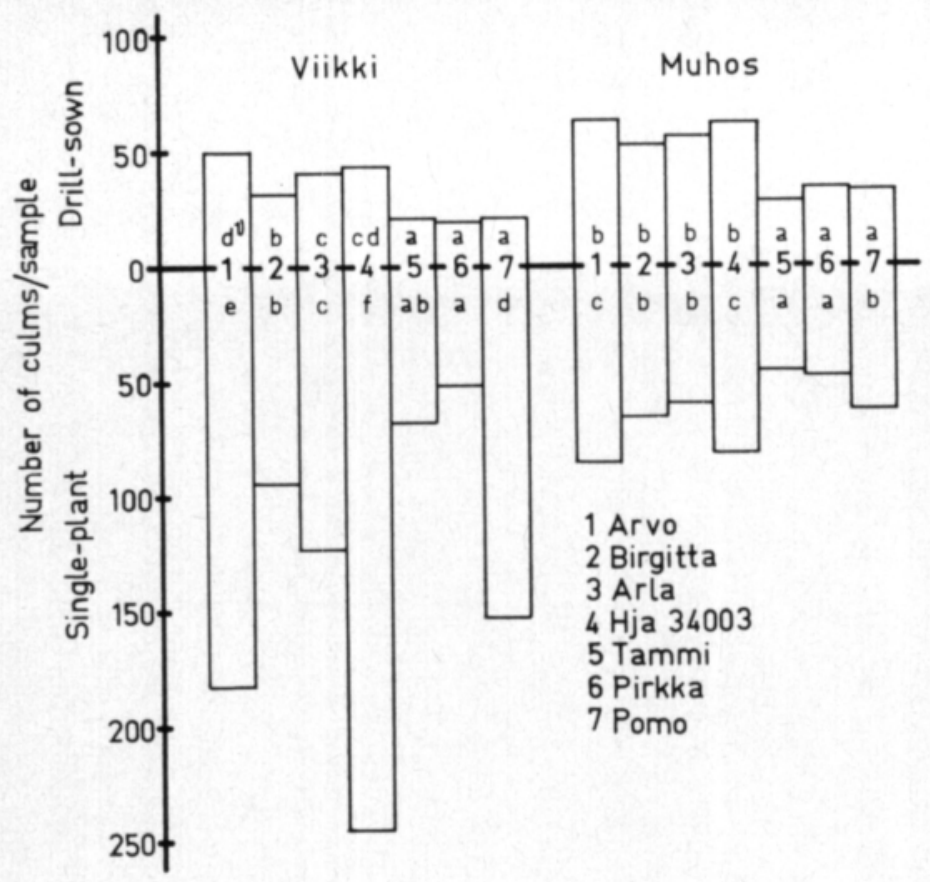

Fig. 8. Number of culms per sample of the barley varieties at full maturity in drill-sown and singleplant trials at Viikki and Muhos.

1) Columns within any location and density group which are marked by the same letter indicate results which in the Duncan test do not differ from each other significantly when $\mathrm{P}=5 \%$.

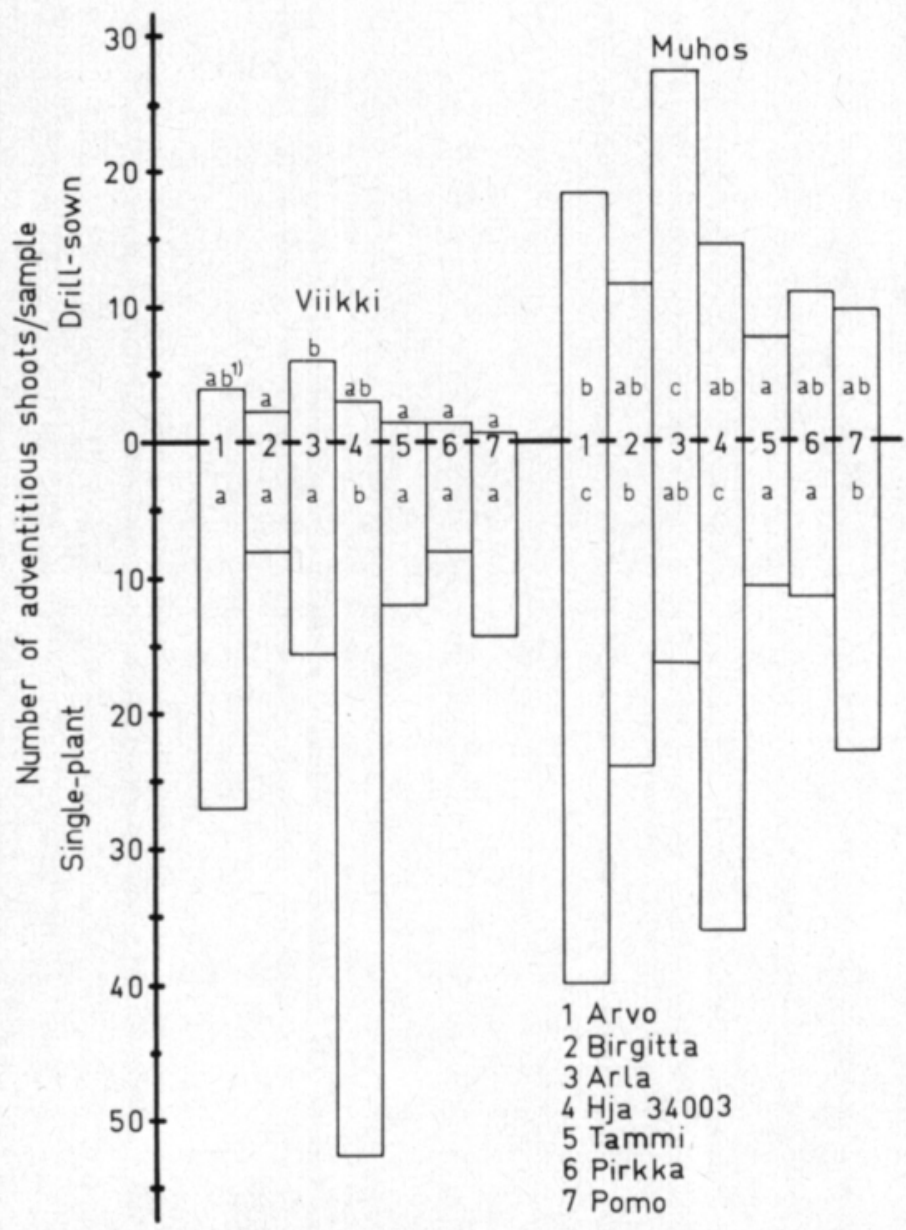

Fig. 9. Number of adventitious shoots per sample of the barley varieties in drill-sown and single-plant trials at Viikki and Muhos.

1) Duncan test. See explanation in Fig. 8. 
Fig. 10. Number of ears per sample of the barley varieties at full maturity in drill-sown and singleplant trials at Viikki and Muhos.

1) Duncan test. See explanation in Fig. 8.

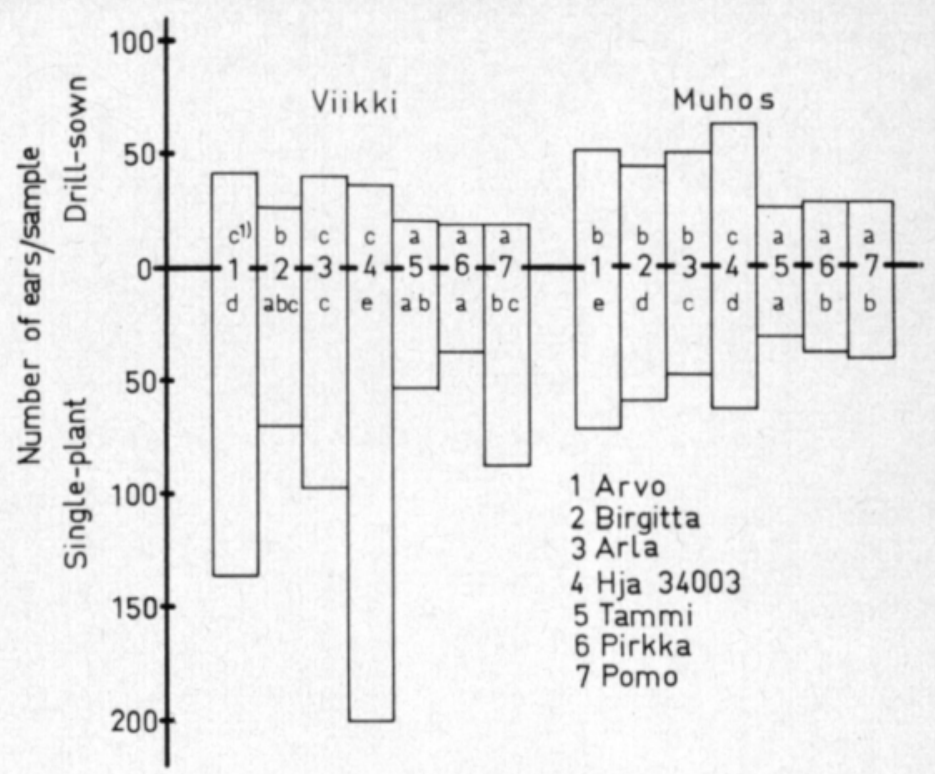

shoots than the multi-rowed ones which was natural in view of the larger numbers of culms in the former. In the drilled trials of both localities the variety Arla had the most numerous adventitious shoots. In the Viikki singleplant trials $\mathrm{Hja} 34003$ differed from all the other varieties by having a many times greater number of adventitious shoots. In the Muhos single-plant trials shooting was most abundant in Arvo and $\mathrm{Hja} 34003$.

\section{Number and length of ears}

In the drill-sown trials the number of ears per sample was only slightly lower than the number of culms. In the single-plant experiments, however, the average number of ears per plant at Viikki was 11 and the number of culms 17 while at Muhos there were 6 ears and 8 culms. Varietal differences in the number of ears per sample (Fig. 10) corresponded to differences in culm numbers.

In ear length there was no significant difference between the localities. Average ear length at Viikki was $7,7 \mathrm{~cm}$ in the single-plant populations and $4,8 \mathrm{~cm}$ in the drilled populations, at Muhos respectively 7,9 and $4,1 \mathrm{~cm}$.

\section{Number of grains per ear}

Grain numbers at the two localities did not differ significantly. Selfevidently, due to the difference in ear structure, multi-rowed varieties produced significantly higher numbers of grains per ear than two-rowed varieties (Fig. 11). At Muhos the average number of grains per ear was in the spaced populations slightly higher than in the drilled ones. At Viikki, reversely, fewer grains were produced in the spaced trials than in the drilled ones and the difference was highly significant in the case of the multi-rowed varieties. The reason for this, in itself unexpected result can possibly be found in the many times larger number of culms in the single-plant trials as compared with the drillsown trials (Fig. 7). Varietal differences within barley type were small. 


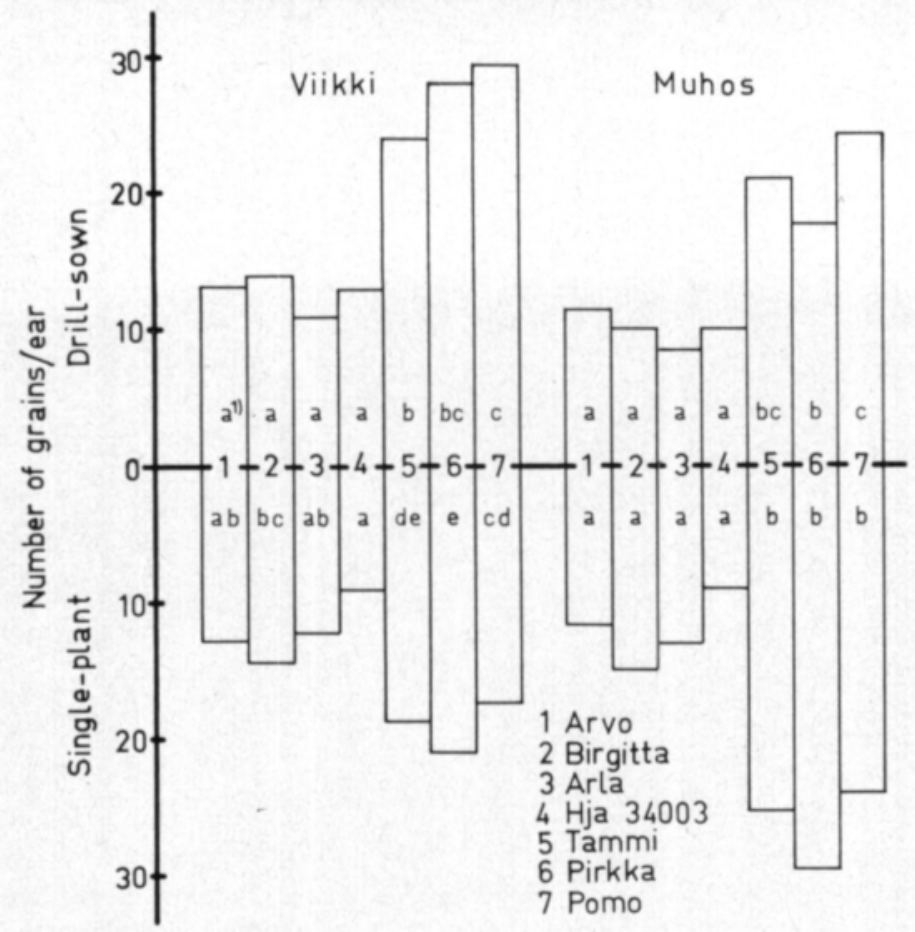

Fig. 11. Number of grains per ear of the barley varieties in drillsown and single-plant trials at Viikki and Muhos.

1) Duncan test. See explanation in Fig. 8.

\section{0-grain weight}

The average 1000-grain weight of the two-rowed varieties was significantly higher than that of the multi-rowed varieties. In the drilled trials the average 1000-grain weights were higher at Muhos $(41,2 \mathrm{~g}$ for the two-rowed and 39,2 for the multi-rowed varieties) than at Viikki $(39,7$ and 35,0 g respectively). In the single-plant trials the two-rowed varieties had a higher 1000-grain weight at Viikki $(47,5 \mathrm{~g})$ than at Muhos $(42,7 \mathrm{~g})$ while the multi-rowed varieties showed no difference between the two localities $(38,5$ and $38,3 \mathrm{~g})$. The two-rowed Birgitta and Arla had the highest 1000-grain weights (Fig. 12). Contrary to all other varieties, grains of Pomo were lighter in spaced than in drilled populations.

\section{Grain yield}

Grain yield, as calculated from the samples taken from the drilled trials, was for both types of barley slightly higher at Muhos than at Viikki (Fig. 13). In the drilled trials there was no difference in grain yield between the two types at either locality. Yields from single-plant trials were very significantly larger at Viikki than at Muhos. At Viikki grain yields of the two-rowed varieties were significantly larger than those of the multi-rowed varieties. In the Muhos single-plant trials the multi-rowed barleys yielded more than the two-rowed barleys but the difference was not statistically significant. Notable varietal differences occurred in single-plant populations only (Fig. 14). The best yielders at Viikki were Arvo, $\mathrm{Hja} 34003$ and Pomo, the poorest was Pirkka. At Muhos the differences between varieties were smaller. It is worth noting, however, that Pirkka in the Muhos single-plant trials yielded significantly better than all the other varieties, Birgitta excepted. 
Fig. 12. 1000-grain weight of the barley varieties in drill-sown and single-plant trials at Viikki and Muhos.

1) Duncan test. See explanation in Fig. 8.

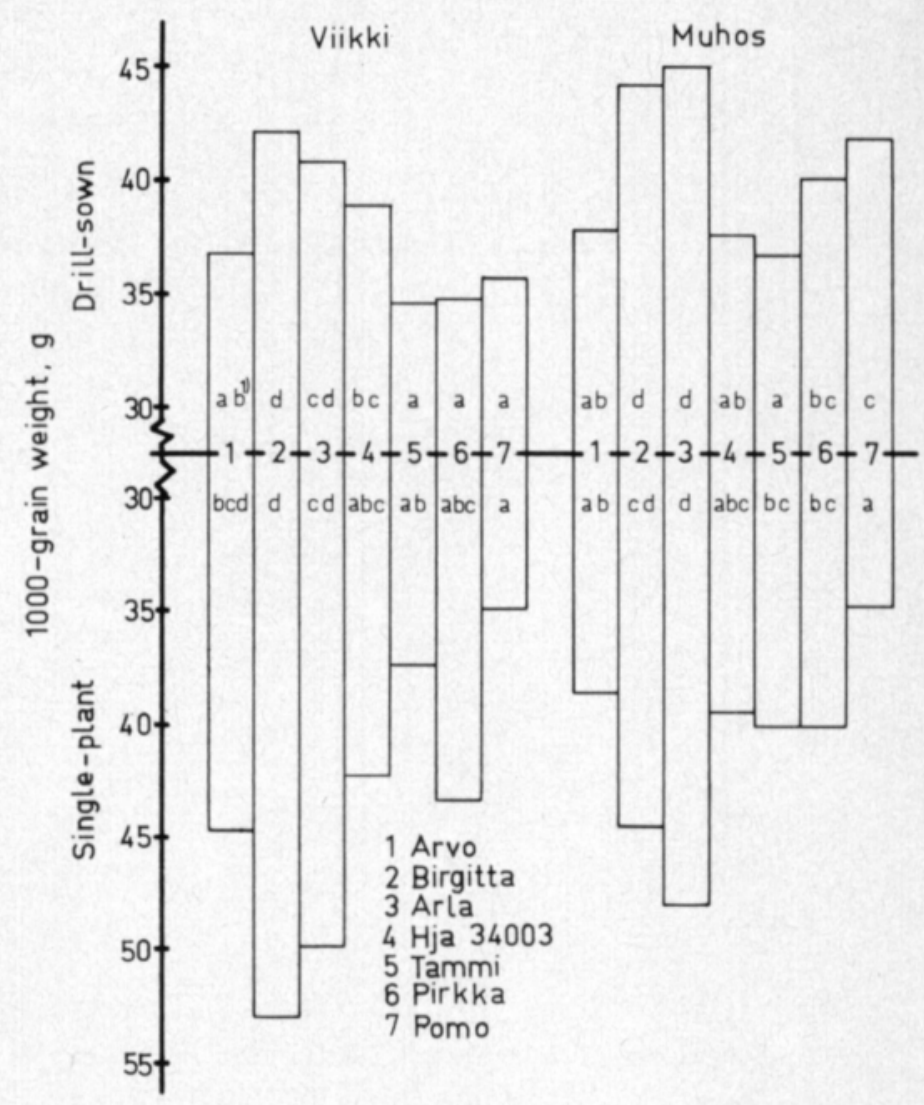

Fig. 13. Grain yield, g per sample of the twoand multi-rowed barley varieties in drill-sown and single-plant trials at Viikki and Muhos.

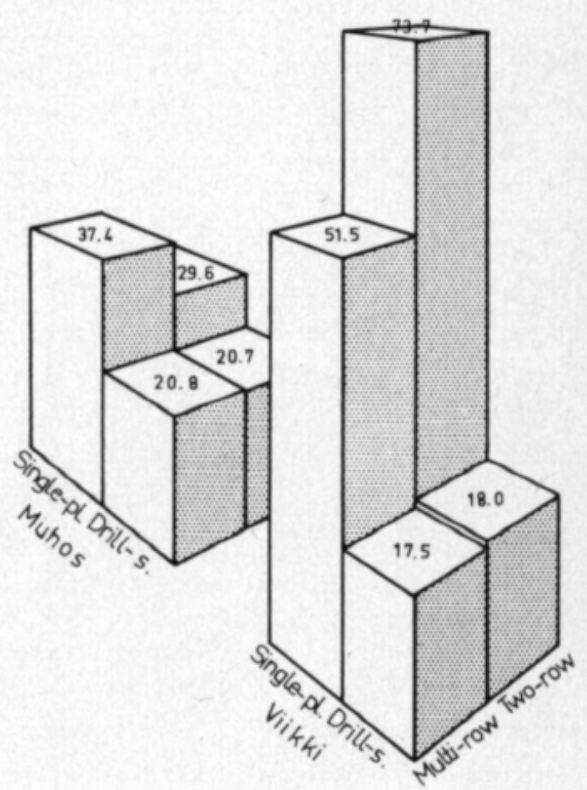




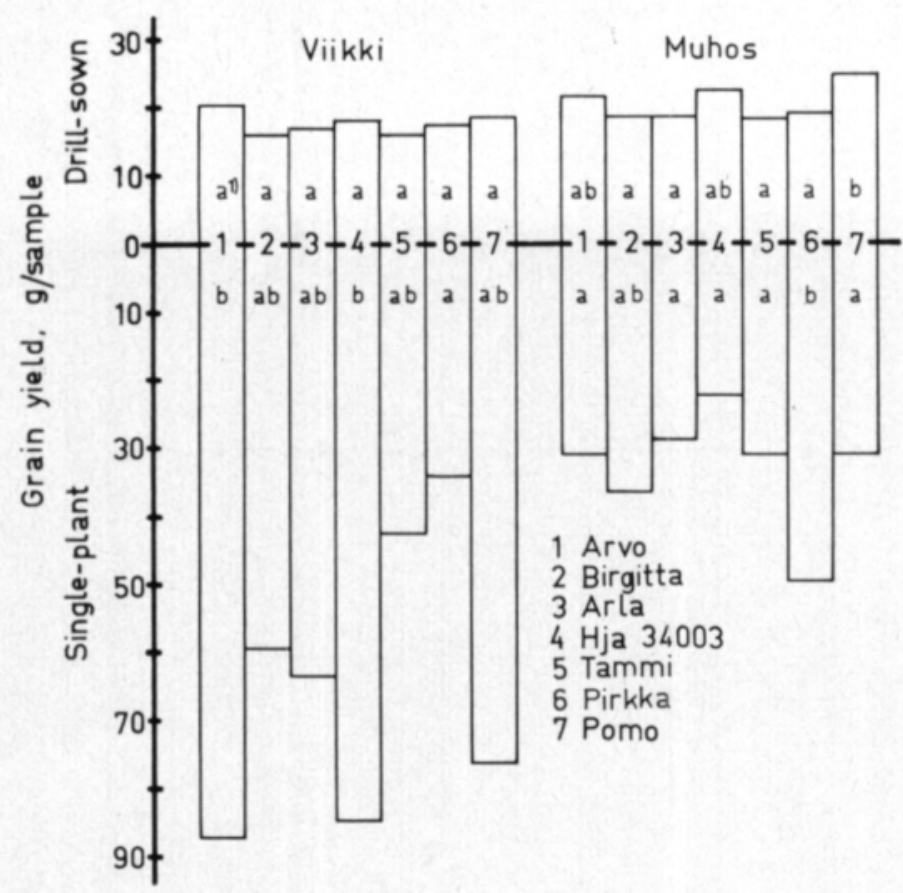

Fig. 14. Grain yield per sample of the barley varieties in drill-sown and single-plant trials at Viikki and Muhos.

1) Duncan test. See explanation in Fig. 8.

In terms of grain yield per hectare, calculated from the yields of entire plots, there was no significant difference between the two barley types when grown at Viikki. At Muhos, however, multi-rowed varieties yielded more than two-rowed varieties. At Viikki the highest-yielding barley was $\mathrm{Hja} 34003$ (Table 2) and at Muhos Pomo, the variety which significantly outyielded most of the others on the basis of the sample analyses as well.

Table 2. Grain yields, $\mathrm{kg}$ per hectare in drill-sown trials

\begin{tabular}{|c|c|c|}
\hline Variety & Viikki & Muhos \\
\hline 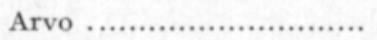 & $\left.3914^{\mathrm{ab} 1}\right)$ & $3063^{\mathrm{a}}$ \\
\hline Birgitta $\ldots \ldots \ldots \ldots \ldots \ldots \ldots \ldots$ & $3667^{\mathrm{ab}}$ & $3015^{\mathrm{a}}$ \\
\hline 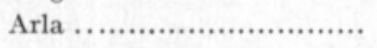 & $3077^{a}$ & $2874^{\mathrm{a}}$ \\
\hline Hja $34003 \ldots \ldots \ldots \ldots \ldots \ldots$ & $3964^{b}$ & $3135^{\mathrm{ab}}$ \\
\hline Tammi ......................... & $3083^{a}$ & $3645^{\text {be }}$ \\
\hline Pirkka ......................... & $3581^{\mathrm{ab}}$ & 3291 abe \\
\hline 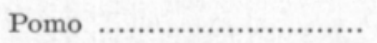 & $3804^{\mathrm{ab}}$ & $3740^{\mathrm{e}}$ \\
\hline
\end{tabular}

1) Grain yields within the same column which are marked with the same letter do not differ from each other significantly in the Duncan test when $P=5 \%$.

\section{Nitrogen content}

Grain nitrogen content was significantly higher in spaced than in drilled populations (Fig. 15). There were no differences due to barley type in this respect but some significant varietal differences did occur. 
Fig. 15. Grain nitrogen content of the barley varieties in drill-sown and single-plant trials at Viikki and Muhos.

1) Duncan test. See explanation in Fig. 8.

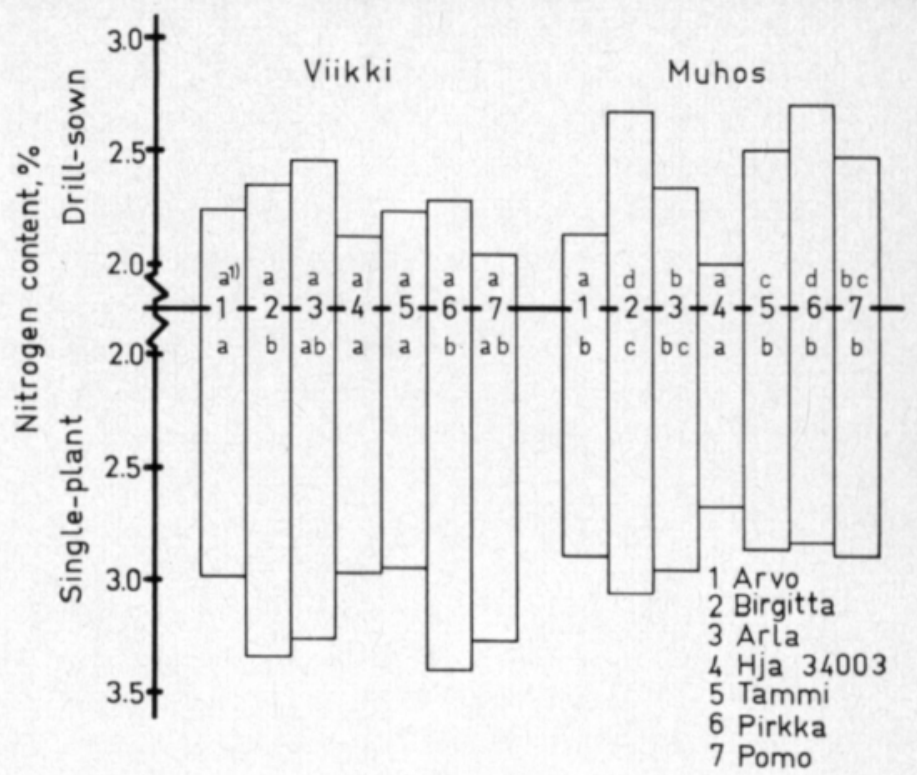

\section{Hectolitre weight}

Hectolitre weights were significantly higher at Viikki than at Muhos. No significant differences were found between barley types or varieties (Table 3).

Table 3. Hectolitre weights, $\mathrm{kg}$, in drill-sown trials

\begin{tabular}{|c|c|c|}
\hline Variety & Viikki & Muhos \\
\hline Arvo $\ldots \ldots \ldots \ldots \ldots \ldots \ldots \ldots \ldots$ & $\left.65,1^{\mathrm{a} 1}\right)$ & $61,1^{a}$ \\
\hline Birgitta ....................... & $64,1^{\mathrm{a}}$ & $60,3^{\mathrm{a}}$ \\
\hline Arla $\ldots \ldots \ldots \ldots \ldots \ldots \ldots \ldots \ldots$ & $62,6^{\mathrm{a}}$ & $60,2^{\mathrm{a}}$ \\
\hline Hja $34003 \ldots \ldots \ldots \ldots \ldots \ldots . . . . . . . .$. & $66,4^{\mathrm{a}}$ & $58,5^{\mathrm{a}}$ \\
\hline Tammi ......................... & $61,7^{\mathrm{a}}$ & $60,0^{\mathrm{a}}$ \\
\hline Pirkka .......................... & $63,5^{\mathrm{a}}$ & $60,1^{\mathrm{a}}$ \\
\hline Pomo .............................. & $61,1^{\mathrm{a}}$ & $58,5^{\mathrm{a}}$ \\
\hline
\end{tabular}

1) Hectolitre weights within the same column which are marked with the same letter do not differ from each other significantly in the Duncan test when $\mathrm{P}=5 \%$.

\section{Discussion}

In accordance with previous greenhouse experiments with the same material (ÄYRÄVÄINEN and PAATELA 1974) there is no evidence from the field trials either that varietal differences in distribution of biological mass between different plant parts were reflected in varietal differences in grain yield. As in greenhouse, Tammi clearly was the least leafy variety in the field as well, and Pomo had a higher than average proportion of leaves especially in the late stages of development. Correspondingly, culms percentage was high in Tammi and low in Pomo. 
Our single-plant experiments gave larger biological and grain yields at Viikki than at Muhos. When grown singly, the plants developed more culms and their overall vegetative growth was more abundant than in normally drilled populations, resulting in a slower developmental rate. At Viikki, under the influence of a longer growing season and higher temperatures during the later stages of development, most of the culms completed their growth and matured normally. At Muhos, were sowing took place about three weeks later than at Viikki, development of the single plants was right from the vegetative phase more rapid than at Viikki and the plants remained smaller in size. Growing period at Muhos was also limited by the early onset of autumn and thus a much larger percentage proportion of culms remained green than at Viikki.

Low temperature has been found more beneficial than high temperature to the production of both biological and grain yields of barley (GUITARD 1960, Faris and Guitard 1969, ÄyräväInen and PaAtela 1974). Since there were only slight temperature differences between the localities Viikki and Muhos in 1971 and 1972, the reasons for the larger biological and grain yields from drilled trials at Muhos as well as for some other differences between the results of the experiments carried out at the two localities must be found elsewhere. One possible explanation is the great difference in daylength. In the experiments of FARIS and GUITARD (1969) for instance, extended photoperiod increased the grain yield of barley with the only exception of the stage from seeding to internode elongation when short daylength proved most favourable.

In order to attain as high yields as possible, various breeding methods and cultivation techniques can be applied to cereals with a view to influencing yield factors such as number of headed culms, number of grains per ear, and size of grain. One of the essential conditions for a high grain yield is, however, a sufficiently large total biological yield, althoug there does not always exist a direct relationship between the biological yield and the grain yield. The biological yield may sometimes exceed the optimum with the result that photosynthesis is inhibited in the lowermost, shaded leaves which thereafter continue to subsist at the expense of upper leaves thus slowing down the accumulation of assimilates in the grain. In an economical yield composition the percentage of grain of total biological yield is the highest possible. In his study of the prerequisites for economical grain production, Niciporovic (1956) suggested the following formula:

$$
\mathrm{K}_{\mathrm{econ}}=\frac{\mathrm{Y}_{\text {econ }}}{\mathrm{Y}_{\text {biol }}}
$$

where $\mathrm{K}_{\text {ccon }}$ is the effiency coefficient for calculation of economical (grain) yield $\mathrm{Y}_{\text {econ }}$ from total biological yield $\mathrm{Y}_{\text {biol }}$. More recently, a simpler and more explicit term 'harvest index' suggested by Donald (1962) has been used instead of 'the coefficient of effectiveness'. Applied to the present barley material the formula gave harvest index or $\mathrm{K}_{\text {econ }}$ values of 0,50 for the drillsown trials at Viikki and 0,43 at Muhos, and 0,30 for the single-plant trials at Viikki and 0,25 at Muhos, the differences being statistically significant (t-test, 
$\mathrm{P}=0,01)$ except for that between the Viikki and Muhos single-plant trials. The results thus show that barley grain was more economically produced in drill-sown than in single-plant populations and in case of the drilled ones, more economically at Viikki than at Muhos.

The better yield of new cereal varieties compared with the old ones is closely associated with their higher harvest index (DoBBEn 1962, WATson et al. 1963). Great differences between varieties have been found in the harvest indices of barley (Thorne 1962, 1963), wheat (DobBen 1962, WAtson et al. 1963) and rice (Donald 1962, Yoshida 1972). According to Bingham (1962) the best ways of improving the ratio of grain to straw weight and yield in cereals is to reduce tiller production, increase the number of shoots surviving to ear and to reduce stem weight. He also mentions selection for more erect leaves, increased net assimilation rate and increased leaf longevity. A single short and strong stem, few small and erect leaves and a large erect ear with awns is Donald's (1968) description of a wheat ideotype designed to give a high grain yield in a crop community. The present study on the harvest index did not reveal any difference between barley types, neither were the differences between varieties statistically significant. In drilled trials the harvest indices of different varieties ranged from 0,46 to 0,55 at Viikki and from 0,38 to 0,48 at Muhos; in spaced trials the corresponding figures were $0,24-0,32$ and $0,18-0,35$ respectively. However, the relative differences between different varieties were, with one exception in drilled and two in spaced populations, about the same at both localities, which affirms YosHIDA's (1972) statement of harvest index being a varietal character.

Correlations between grain yield and the factors affecting it were calculated separately for the two-rowed and multi-rowed varieties (Table 4). Those between biological yield and grain yield were positive for both types of barley and highly significant except for the multi-rowed varieties in single-plant experiments. As anticipated, biological yield and number of ears were in significant positive correlation with each other. Likewise, increasing biological yield of the multi-rowed varieties in drilled trials was accompanied by a clear increase in 1000-grain weight. In the single-plant trials, however, abundant vegetative growth of the multi-rowed varieties with a high number of culms was associated with decreases in grain weight and number of grains per ear.

Of the actual yield components - number of ears, 1000-grain weight, and number of grains per ear - only the number of ears had a significant influence on the grain yield of the two-rowed varieties in normally drilled stands $(\mathrm{r}=$ $+0,632 * *)$ while 1000 -grain weight and the number of grains per ear were found insignificant. In the multi-rowed varieties there was no correlation between the number of ears and the grain yield, and rising 1000-grain weight had but a marginal, although positive, effect on the yield of the multi-rowed barleys. The most significant factor was the number of grains per ear $(r=$ $+0,594 * *)$.

In spaced populations there were for both types of barley positive correlations between all the yield components and the grain yield. In the two-rowed varieties number of ears and number of grains per ear were in significant positive correlations with the grain yield; in the multi-rowed varieties the number of 


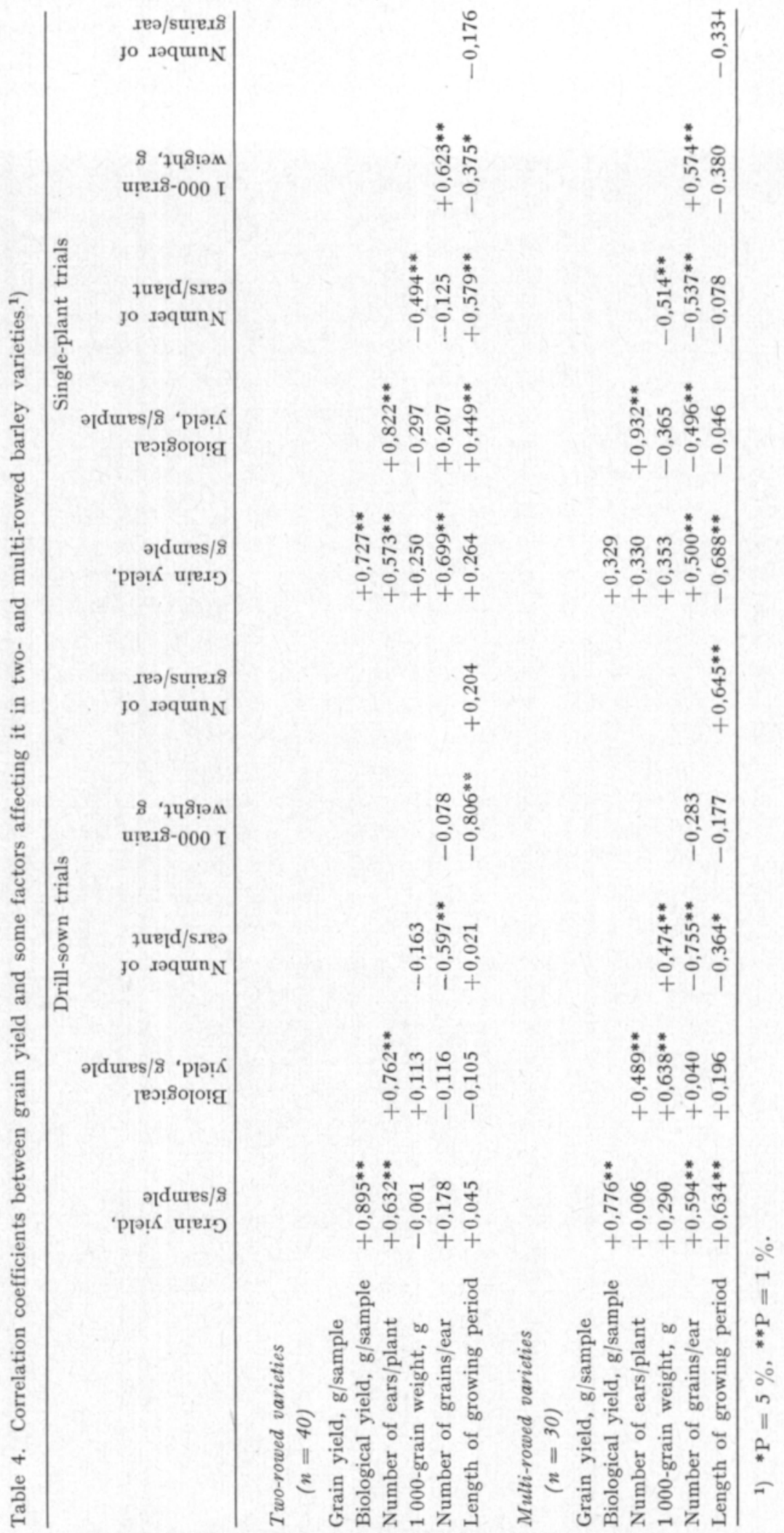


grains per ear was alone in a significant positive correlation with the grain yield while the other yield components were of less importance:

In the drill-sown trials and in both types of barley, number of ears and number of grains per ear were in significant negative correlation with each other. In the single-plant trials the corresponding correlation was not significant except for the multi-rowed varieties. Grain weight of the multi-rowed varieties increased as the number of ears increased in the normally drilled stands; there was no noteworthy correlation in this respect for the two-rowed varieties. In the single-plant trials there was for both types of barley a significant negative correlation between 1000-grain weight and number of ears. Another special feature of the single-plant trials was the significant positive correlation between 1000-grain weight and number of grains per ear.

In the drill-sown experiments, with an average growing period of 90 days, increasing length of the growing period caused an increase in the grain yield of the multi-rowed varieties $\left(\mathrm{r}=+0,634^{* *}\right)$; this was due to the beneficial effect of the extension of the growing period on the number of grains per ear $\left(\mathrm{r}=+0,645^{* *}\right)$. In the two-rowed varieties grain yield and growing period were not correlated $(\mathrm{r}=+0,045)$. In the single-plant trials, which in general required a longer growing period, the effect of extension of the period had a reverse effect on the grain yield of the multi-rowed varieties $\left(\mathrm{r}=-0,688^{* *}\right)$ as compared with the drill-sown experiments. The effect of length of growing period on the numbers of ears and grains was variable depending on growth density and type of barley. Extended growing period always reduced the 1000 -grain weight.

\section{REFERENCES}

Äyräväinen, K. \& PAAtela, J. 1974. The effect of temperature and growth density on the development and yield of two- and multi-rowed barley varieties. J. Scient. Agric. Soc. Finl. 46: 11-31.

Bingham, J. 1969. The physiological determinants of grain yield in cereals. Agric. Progress. (J. Agric. Educ. Ass.) 44: 30-42.

Black, J. N. \& Watson, D. J. 1960. Photosynthesis and the theory of obtaining high crop yields, by A. A. Niciporovic. An abstract with commentary. Field Crop Abstracts 13: $169-175$.

DoвBEN, W. H. van 1962. Influence of temperature and light conditions on dry matter distribution, development rate and yield in arable crops. Neth. J. Agric. Sci. 10:377-389.

Donald, C. M. 1962. In search of yield. J. Aust. Inst. Agric. Sci. 28: 171-178.

,- 1968 . The breeding of crop ideotypes. Euphytica 17: 385-403.

Engledow, F. L. \& Wadham, S. M. 1923. Investigation on yield in the cereals. Part I. J. Agric. Sci. 13: 390-439.

FARIS, D. G. \& GuITARD, A. A. 1969. Yield and primary culm yield components of two spring barley cultivars as influenced by temperature, daylength and growth stage. Can. J. Plant Sci. 49: 701-713.

Guitard, A. A. 1960. The influence of variety, temperature, and stage of growth on the response of spring barley to photoperiod. Can. J. Plant Sci. 40:65-80.

LANger, R. H. M. 1967. Physiological approaches to yield determination in wheat and barley. Field Crop Abstracts 20: 101-106. 
Niciporovic, A. A. 1956. 15th Timirjazev Lecture. USSR Acad. Sci. (Ref. Black, J. N. and Watson, D. J. 1960.)

Thorne, G. N. 1962. Survival of tillers and distribution of dry matter between ear and shoot of barley varieties. Ann. Bot. 26: $37-54$.

- 1963. Varietal differences in photosynthesis of ears and leaves of barley. Ann. Bot. 27: $155-174$.

-1966 . Physiological aspects of grain yield in cereals. The growth of cereals and grasses: 88-118. Ed. Milthorpe, F. L. and Ivins. J. D. London.

Watson, D. J., Thorne, G. N. \& French, S. A. W. 1963. Analysis of growth and yield of winter and spring wheats. Ann. Bot. 27: 1-22.

YoshidA, S. 1972. Physiological aspects of grain yield. Ann. Rev. Plant Physiol. 23: 437-464.

Ms received April 25, 1975

\title{
SELOSTUS
}

\section{Kaksi- ja monitahoisen ohran sadonmuodostuksesta kylvö- ja yksilökokeissa Etelä- ja Pohjois-Suomessa.}

\author{
KIRSTI ÄYRÄvÄINEN \\ Kasvinviljelytieteen laitos, Helsingin yliopisto, $00710 \mathrm{Helsinki}$
}

Viikissä ja Muhoksella suoritetuissa kenttäkokeissa pyrittiin selvittämään kaksi- ja monitahoisen ohran sadon määräytymistä ja biomassan jakautumista kasvissa kehityksen eri vaiheissa normaalissa kylvötiheydessä ja yksilökylvöissä. Kokeissa oli seitsemän lajiketta, joista kaksitahoisia Arvo, Birgitta, Arla ja Hja 34003 sekä monitahoisia Tammi, Pirkka ja Pomo.

Kehitys oli kylvökokeissa paljon nopeampaa kuin yksilökokeissa. Kehitys oli nopeampaa Muhoksella kuin Viikissä, varsinkin vegetatiivisen vaiheen aikana, mutta tuleentuminen vaati kaksitahoisilla lajikkeilla niin pitkän ajan, että kokonaiskasvuaika muodostui niillä pidemmäksi Muhoksella kuin Viikissä.

Biomassan määrä yksilöä kohti oli yksilökokeissa moninkertainen verrattuna kylvökokeisiin (Kuva 2). Yksilökokeissa saatiin Viikissä suuremmat biosadot kuin Muhoksella ja molemmilla paikkakunnilla kaksitahoisista lajikkeista suuremmat sadot kuin monitahoisista (Kuva 2); kylvökokeissa biosadot olivat Muhoksella suuremmat kuin Viikissä. Lehtien prosenttinen osuus biosadosta oli yksilökokeissa suurempi kuin kylvökokeissa (Kuvat 3 ja 4). Yksilökokeissa oli molemmilla paikkakunnilla monitahoisissa lajikkeissa lehtien osuus kasvukauden loppupuolella suurempi kuin kaksitahoisissa lajikkeissa; kylvökokeissa oli lehtien osuus Viikissä merkitsevästi suurempi ja Muhoksella merkitsevästi pienempi kaksi- kuin monitahoisissa lajikkeissa. Lajikkeista oli Pomo runsaslehtisin ja Tammi vähälehtisin; vastaavasti Pomossa oli korsien prosenttinen osuus pienin ja Tammessa suurin. Tähkien osuus biosadosta oli tuleentuneessa kasvustossa 53-60\% kylvökokeissa ja 32-47\% yksilökokeissa. Paikkakuntien kesken ei eroa ollut. Korsiluku yksilöä kohti kasvoi yksilökokeissa moninkertaiseksi kasvun edistyessä, kylvökokeissa se pysyi jokseenkin samana toisesta korjuukerrasta (1. solmun muodostuttua) lähtien (Kuva 7). Viikissä oli yksilökokeissa korsia jopa moninkertainen määrä kylvökokeisiin verrattuna, Muhoksella ero oli vähäinen (Kuva 8). Kylvökokeissa oli kaikissa monitahoisissa lajikkeissa korsia merkitsevästi vähemmän kuin kaksitahoisissa lajikkeissa (Kuva 8). Jälkiversoja muodostui Muhoksella runsaasti molemmissa tiheyksissä, Viikissä vain yksilökokeissa (Kuva 9). Tähkän jyväluvussa ei paikkakuntien kesken ollut eroja. Monitahoisissa lajikkeissa oli tähkän rakenteesta johtuen luonnollisestikin jyviä enemmän kuin kaksitahoisissa lajikkeissa (Kuva 11). Kaksitahoisissa lajikkeissa oli 1000 jyvän paino keskimäärin merkitsevästi suurempi kuin monitahoisissa lajikkeissa. Kylvökokeissa olivat 1000 jyvån painot molemmissa ohratyypeissä suuremmat Muhoksella kuin Viikissä; yksilökokeissa ei moni- 
tahoisissa lajikkeissa ollut eroa paikkakuntien kesken, kaksitahoisissa oli Viikissä suurempi 1000 jyvän paino kuin Muhoksella (Kuva 12). Jyväsato oli normaalissa kylvötiheydessä Muhoksella niukasti suurempi kuin Viikissä (Kuva 13) ja yksilökokeissa merkitsevästi suurempi Viikissä kuin Muhoksella. Ohratyyppien välillä ei kylvökokeissa ollut eroa; yksilökokeissa saatiin Viikissä kaksitahoisista lajikkeista merkitsevästi suurempi jyväsato kuin monitahoisista lajikkeista, Muhoksella taas monitahoiset antoivat kaksitahoisia runsaamman jyväsadon. Muhoksen kylvőkokeista saatiin Pomosta Arvoa ja Hja 34003:a niukasti suurempi ja muita lajikkeita merkitsevästi suurempi sato (Kuva 14) muiden lajikkeiden ollessa keskenäăn samanveroisia. Pirkka oli yksilökokeissa jyväsatonsa puolesta heikoin lajike Viikissä ja paras Muhoksella (Kuva 14) muiden lajike-erojen ollessa yksilökokeissakin vähäisiä.

Ohran kenttäkokeet eivät osoittaneet, että lajikkeiden välisillä eroilla jyväsadon määrässä olisi ollut yhteyttä todettuihin eroihin biomassan jakautumisessa kasvin eri osiin. Muhoksella todettuihin suurempiin jyväsatoihin kylvökokeissa sekä mahdollisesti myös joihinkin muihin eroihin Viikin ja Muhoksen kokeiden tuloksissa oletetaan päivän pituudella olleen suurin merkitys, koska paikkakuntien väliset erot lämpötiloissa olivat koevuosina melko vähäiset.

Satoindeksi (harvest index eli jyväsadon prosenttinen osuus biosadosta) oli kylvökokeissa suurempi kuin yksilökokeissa ja mitä kylvökokeisiin tulee, suurempi Viikissä kuin Muhoksella. Ohratyyppien välillä ei satoindeksissä ollut eroa eivätkä lajikkeiden välisetkään erot olleet tilastollisesti merkitseviä.

Jyväsadon, biosadon, satokomponenttien ja kasvuajan väliset korrelaatiot on käsitelty kirjoituksen lopussa (Taulukko 4). 